\title{
The Political Economy of Policy Failure in Zambia ${ }^{1}$
}

\author{
by \\ Arne Bigsten and Steve Kayizzi-Mugerwa \\ Working Papers in Economics no 23 \\ May 2000 \\ Department of Economics \\ Göteborg University
}

\begin{abstract}
Zambia's experience in the 1990s illustrates that, on their own, policy changes will not redress decades of mismanagement, especially when the degree of commitment of the elite remains unaltered. In 1991, the Movement for Multiparty Democracy won the elections on a reform platform, promising to reverse the economic decline and to introduce more inclusive politics. Though macroeconomic stabilisation and market reforms were successfully implemented, the new government was less successful in introducing public-sector reforms and those related to governance. Even its privatisation efforts became more difficult as the focus reverted to the copper mines. These latter reforms have more clear-cut costs for stakeholders and were resisted. Politics continue to be the main stumbling block to durable reform. The country is yet to establish a level of confidence that is required to attract sufficient amounts of domestic and foreign investment that can spur sustainable growth. With regard to the role of donors, aid to Zambia, or even its temporary withdrawal, has been a poor basis for inducing reform. Establishing a high degree of reform ownership in Zambia is important for enhancing programme sustainability.
\end{abstract}

Keywords: Policy, dependence, reform, aid, politics

JEL-classification: $\mathrm{O} 2$

Department of Economics

School of Economics and Commercial Law

Göteborg University

P.O.Box 640

SE 40530 Göteborg

Tel: $+46-31-7731358$ and 7735247

Fax: +46-31.7731326

E-mail: Arne.Bigsten@economics.gu.se, Steve.Mugerwa@economics.gu.se

\footnotetext{
${ }^{1}$ Thanks for comments are due to Robert Keller.
} 


\section{Introduction}

In Africa, Zambia presents a stark example of the combined effects of external shocks and domestic policy failures. Following a post-independence decade of robust growth, per capita income started to fall in the mid-1970s, with the collapse of copper prices. For a while the government, which had increasingly emphasised state controls in both resource allocation and investment, tried to postpone adjustment. It depended on borrowed money, which led to serious foreign indebtedness. Towards the end of the 1970s, it became obvious that economic reforms were necessary to revive the economy and preserve social welfare. During the 1980s, Kaunda's government initiated a series of structural adjustment programmes, with the support of the international financial institutions. However, under serious domestic opposition, especially from miners on the Copperbelt, the government invariably failed to implement important components of the reform packages.

In 1991, a newly formed political party, the Movement for Multiparty Democracy (MMD), won power on a reform platform. The new government undertook an extensive macroeconomic and market liberalisation programme. Many of the policies adopted were of the 'stroke of the pen' type such as the freeing of the exchange rate and lower tariffs. Still, the government also embarked on an ambitious privatisation programme, which was declared among the most successful in Africa, that is before the government was embroiled in the difficulties related to the privatisation of the mining conglomerate, Zambia Consolidated Copper Mines (ZCCM). In spite of the liberal policies, the investment response has been poor, and per capita incomes have continued to decline.

This paper discusses why reforms were harder to implement than anticipated and looks at the impact of the failed policies on the economy. While the problem of slow or poorly implemented reforms was largely a result of inadequate policies, and thus to blame on domestic politics, Zambia also faced an extremely severe debt burden during the reform period. Part of the policy challenge was thus to devise a policy that dealt adequately with the issue of debt, while at the same time making optimal use of donor aid. With respect to both aid and debt, the role and behaviour of donor and international financial institutions have been important. We will, thus, also address the question whether another type of donor-recipient relationship could have contributed to a better policy outcome.

\section{Theoretical aspects}

Recent years have seen a number of attempts to explain the causes of persistent policy failure in Africa in general and among resource-rich Sub-Saharan countries in particular (see e.g. Sachs, Warner, 1997, IMF, 1998). Among the most recent debates has been that related to geography. It has been argued that countries in the tropics have a disadvantage in being located in an area prone to both disease and adverse weather shocks. This has slowed down the accumulation of human capital and the development of a dynamic agricultural sector. The impact of reform policies has thus been limited and in any case not beyond reversal. This debate is related to the earlier ones on the Dutch disease impacts of mineral production. As in the case of geography, the ownership of huge mineral deposits exposes the economy to 
patterns of domestic behaviour on which it has little control. First, to exploit the resources, government undertakes huge initial investments, which are largely irreversible. The huge size of the commitment ensures that resources continue to flow to the areas where mineral exploitation is concentrated, often at the expense of the other regions of the country. The mining activity by itself also has relatively little forward or backward linkages that can stimulate more broad-based development (Hirschman, 1958). The 'encashment' of mineral incomes is also bound to have a huge impact on the urban sectors and on the fiscal standing of the government. During mineral booms, most governments behave as if the inflows of resources are permanent, with new projects, including import substituting ones embarked on. The basic economic structures are thus distorted, with the protected industry expanding, while agriculture and unprotected manufacturing contract. When the boom turns to bust, the country becomes very vulnerable. ${ }^{2}$

However, while the issues of geography and Dutch disease imply that some of the negative policy outcomes are unavoidable, it is being increasingly argued that bad policies aside, there are also a number of institutional issues that impinge on growth. For many African countries a central question is, therefore, what might be required for growth-supporting institutions to develop. A government whose primary concern is its own short-term survival is unlikely to develop institutions and regulations that are good for economic growth. With special interest groups at centre stage, trying to push through their demands or pursuing various rent-seeking activities, the implied distortions are bound to lead to static inefficiency. Resources are thus wasted and investors become cautious. A notion that has been central in the analysis of the Asian success stories is that of "shared growth", arguing that if they are to participate actively, the mass of the population must benefit from growth. However, it is not only the general population that must be included, but also competing elites must be allowed to take part. To achieve the benefits of shared growth, therefore, there is need for a bureaucracy of high quality, which is sufficiently independent of pressure groups.

The political economy of reform also relates to the recent democratic transition in Africa, once seen as the beginning of a new economic dispensation. However, Africa's new multiparty democracies remain extremely vulnerable, not least because of the still poor performance of the economies (Bratton, van de Walle, 1997). Where the economic and social conditions are not conducive to democratic behaviour, the survival of the new governments will partly depend on the commitment and good will of the new political elite and partly on the commitment to the democratic process of the ordinary citizens. None of this can be taken for granted, however. Of its own volition, the political elite is often unwilling to allow democratic rights. However, direct pressure from the international community has sometimes been more disruptive than helpful. Moreover, the international financial institutions have not been very accurate in their projections of either economic trends or the political behaviour of recipient governments. Deaton (1999) shows, for example, that the projections of copper prices done by the World Bank from the first half of the 1970s onwards have been wildly exaggerated. Civil societies in Africa, including religious organisations, trade unions and other movements, are thus faced with the formidable task of mobilising the population towards the culture of democracy and accountable government, with few means and little precedent.

\footnotetext{
${ }^{2}$ Sachs and Warner (1995) show that countries with a high share of resources in their exports in 1971 grew slower than the average between 1971 and 1989.
} 


\section{The Kaunda years, $1964-1991^{3}$}

Zambia, as its first President Kenneth Kaunda once remarked, was born with a copper spoon in its mouth. Its recent history, notably after Independence in 1964, has been intertwined with the fortunes of firms in the mining sector, especially those on the Copperbelt. The mining companies were traditionally the most important employers in the economy, and copper itself was the biggest generator of foreign exchange. It thus provided the basis for the import-substituting industrialisation efforts that the government had embarked on in the 1960s. The Zambian Government considered the sector so important for its development that the mines were nationalised by the beginning of the 1970s. Above all, however, miners and other workers in the mines became, with time, among the most vocal and politically active groups of employees in the country, with much influence on wages and employment policies throughout the rest of the economy.

With the global recession of the 1970s copper incomes fell dramatically. The government was initially not willing to adjust, but borrowed large amounts of money to maintain the copper mines and the public sector, in the process building up a large debt. Zambia tried to deal with the external shock not by serious economic adjustment but with increased regulations. Notably, in an attempt to halt the decline in real wages, the government tightened the regulation of consumer prices and expanded its subsidies on basic commodities. A system of import licensing and administrative foreign exchange allocation was introduced. In 1980, subsidies claimed as much as 20 per cent of the government budget. The control of prices for basic commodities also meant that many state-owned companies made losses, which were covered via the budget.

The first adjustment programme, with IMF backing, was introduced in 1978. This Action Programme led to a certain measure of stabilisation, but the government failed to maintain reform momentum. Another structural adjustment programme was embarked on in 1983, with the major goal of correcting price distortions. Included was the decontrol of interest rates, deregulation of prices, and general reduction of tariffs. The government also sought to reform the parastatals, as well as the taxation system. A notable feature of the programme was its emphasis on raising agricultural production, which would be achieved by agricultural producer-price increases. However, as in earlier attempts, the success of the new programme was conditioned on support for the policies by the elite and urban dwellers. This was doubtful, since the switch from administrative controls to market forces directly threatened groups in charge of the control apparatus and to whom the rents accrued.

Inflation and money supply were under control during the Action Programme, but around 1983 inflationary pressures re-emerged. The government then tried to control demand. It froze wages as well as government employment, and managed, thereby, to reduce the fiscal deficit during the first years of the programme. In the debate, much of the blame for the increase in inflation was put on the rapid depreciation of the exchange rate. The latter became a focal point in the power struggle between those in favour of continued economic controls and those who supported liberalisation. The government embarked on a crawling-peg system, and in 1985 it

\footnotetext{
${ }^{3}$ The presentation draws on Andersson, Bigsten, and Persson (2000).
} 
introduced a full-fledged auctioning of foreign currency. However, by mid-1986, speculation and excessive borrowing from the commercial banks to purchase dollars led to a rapid depreciation of the Kwacha, which in turn led to rampant inflation and loss of purchasing power for wage earners. The food riots in the Copperbelt showed how explosive the situation was becoming. The main problem with the reforms was thus that they tended to undermine the position of the ruling party's main political constituencies (see Bates and Collier, 1993).

Following broad criticism of the reform programme, President Kaunda replaced key members of his economic policy team in April 1986. The shift culminated in May 1987 in the abandonment of the IMF-supported adjustment programme altogether, putting an end to the most sustained reform attempt during the Kaunda era. With the IMF-backed programme blamed for increased malnutrition and death among the population, the government instead introduced the New Economic Recovery Programme (NERP). This implied a partial return to the command economy. Growth was to be through "own resources". Among the policies advocated were: 1) a fixed exchange rate, which would be determined by a foreign exchange allocation committee; 2) price control of some 23 "strategic" commodities; 3) fixed interest rates; 4) a ceiling on debt servicing at 10 per cent of export earnings. Thanks to reduced government spending and the moratorium on debt service, the NERP resulted in a reduction of the fiscal deficit. However, the need to finance the bumper harvest of 1988 put pressure on public expenditures once again. In January 1989 food coupons were introduced in an unsuccessful bid to eliminate food subsidies, but without hurting the poorest households.

It was now becoming increasingly clear that UNIP's heterodox policy approach was not working. Thus in July of 1989 the government decontrolled prices for all goods except maize and several elements of the liberalisation package of the 1980s were reintroduced. The result was a fairly comprehensive structural adjustment programme with traditional instruments, such as tight monetary and fiscal policies, used in an attempt to stabilise the economy. As opposed to the new abandoned NERP, structural adjustment was to be achieved through increased reliance on market prices and trade liberalisation. Accompanying these were further reforms in the civil service and the parastatal sector.

After some initial progress, the programme almost collapsed in late 1991 due to the pending presidential and parliamentary elections. The government began to backtrack on reforms, as it switched to a short-term policy aimed at winning the support of important electoral groups. The removal of subsidies on maize and fertilisers was put on hold, there was little progress on privatisation, and money supply growth remained above programme targets, while serious overruns on most of the expenditure targets, caused mainly by large salary increases to civil service employees in the run-up to the elections, disrupted the fiscal integrity of the budget. Consequently, most donors including the World Bank froze their support to the programme just before the elections in 1991.

When evaluating developments during this period, it is clear that copper dependence had become a source of economic inflexibility and external shocks. The culture of subsidies, ranging from food to housing, which the large mineral incomes had helped to sustain, became a serious liability in this era of economic disruption and 
diminished growth. The subsidies enjoyed by urban consumers had become broadly accepted entitlements, which the government could only remove at high political cost. The import-substitution industry, which had thrived on high tariffs, became a major victim of the decline of the copper sector. Rationing of goods and services became the order of the day, and a powerful committee was set up to allocate foreign exchange to 'priority' sectors and needs. As a result, rent-seekers became a powerful group, able to exercise their veto on any prospective reforms.

In politics, the affluence generated by a rapidly growing economy in the 1960s had enabled the government to exercise broad patronage and for the President to experiment with a version of a socialist approach to development which he called 'Humanism'. It espoused the importance of the government's lead in development, and in 1973 the country became a one-party state. But even after the government had reluctantly embarked on macroeconomic reforms in the 1980s, with support from the World Bank and the IMF, the partiality for government controls persisted. By the mid-1980s there were already a number of reform-minded technocrats in place at the Ministry of Finance and the Bank of Zambia, but they received very limited support from the political leadership. There was an ideological commitment to the statecontrolled system, with leading bureaucrats and politicians remaining unconvinced that an outward orientation would generate economic growth. There was still considerable faith in structuralist ideas and the benefits of pursuing an importsubstitution industrialisation (ISI) strategy (Kayizzi-Mugerwa, 1997).

\section{Reforms under the MMD since 1991}

The opposition won the elections in 1991 on a liberal platform. It wrote in its election manifesto that "the government restricts itself to rehabilitate and build economic infrastructure with a small public sector in the midst of a basically private enterprise economy' (MMD 1991, p.14). The new party was a fairly broad coalition of trade unions, business interests, intellectuals and students. It is the ultimate irony of Zambian politics that Kaunda's successor, Chiluba, would emerge from among employees of the mining sector, raised on the Copperbelt. The new government took advantage of its broad popular support and tried to distinguish itself from the old government that was associated with economic controls and lack of credibility in managing the reform process. As soon as it was elected, it introduced its Economic Reform Program (ERP) with the goal of arresting the economic decline. Over the 1980s the Zambian economy had declined by close to a third. The donors responded to the government's efforts by resuming their support to the Zambia, with aid, at close to US\$1.5 billion, reaching its all time peak, in 1992.

During the first two years there was rapid liberalisation of external trade and payments system, and a movement towards a market-determined exchange rate. A policy of rapid depreciation was initiated, with the rate of retention of export proceeds increased from 50 per cent to 100 per cent. Further liberalisation saw the government adopting a negative list for imports under an Open General Licence system, as opposed to a detailed one used earlier. A system of bureau de change was introduced together with an official crawl in October 1992. In December of the same year, the exchange rate system was unified and determined by the bureau de change rate. During this year the Kwacha experienced a real depreciation for the first time since 1986 (Adam, Bevan and McBrady, 1993a). By March 1993, most foreign 
exchange controls on current transactions had been removed. From early 1994 the currency became fully convertible. In 1996 the government even allowed the ZCCM to retain its foreign exchange earnings and to supply the market directly if it so chose. Over a period of five years all licensing and quantitative restrictions on imports and exports were removed, and the tariff structure was rationalised. The maximum rate came down from $100 \%$ to $25 \%$ and the number of bands from 11 to 4. Thus, already by 1994, Zambia had one of the most liberal foreign exchange regimes in SSA.

Donors responded to this by agreeing a substantial debt reduction for the country of 0.8 billion USD in 1993. Since then, with the deterioration of the policy environment, debt write-offs have been limited and the stock of debt has begun to increase again. Still, the debt service itself has declined due to the shift to loans of a more concessionary nature. However, the country is far from a sustainable debt position.

Although the combined effects of a large devaluation, decontrol of prices and a highly liquid economy had led to high inflation, the government had regained a measure of control by mid-1993. Inflation has since fallen substantially, though remaining fairly high (Table 1).

Table 1: Prices annual changes by income group and residence in per cent, 1990-98

\begin{tabular}{llllllllll}
\hline & 1990 & 1991 & 1992 & 1993 & 1994 & 1995 & 1996 & 1997 & 1998 \\
\hline Low income urban & 110 & 97.6 & 178.3 & 182.7 & 53.1 & 35.8 & 42.0 & 23.3 & 23.7 \\
High income urban & 95.7 & 104.4 & 150 & 176.1 & 57.5 & 35.3 & 39.2 & 24.9 & 24.9 \\
Nonurban & 104.8 & 95.3 & 169.0 & 188.1 & 53.6 & 34.2 & 46.3 & 24.7 & 24.8 \\
\hline
\end{tabular}

Source: Central Statistical Office, Quarterly Statistics

The programme has implied a tight fiscal and monetary policy. A cash budget was introduced in 1993. This meant that expenditures would be based on available funds, with the Bank of Zambia no longer in a position to support deficit financing (Mwenda, 1999). This would make it impossible for the government to resort to money printing to cover expenses. In a situation with serious problems of timeinconsistency, and thus of discretionary fiscal policies, this may have been the best option available. Still, compliance has been less than perfect and the Bank of Zambia provided some short-term bridging finance (Adam and Bevan, 1996).

Aside from the cash budget, the government has also attempted to balance the budget by increasing revenue. In 1993, a Revenue Board was introduced, with a value-added tax (VAT) put in place in July 1995, while user fees have been introduced for most social services. Still, the government has failed to increase resource mobilisation significantly (Table 2 ).

Table 2: Revenue in per cent of GDP

\begin{tabular}{llllllllll}
\hline & 1990 & 1991 & 1992 & 1993 & 1994 & 1995 & 1996 & 1997 & 1998 \\
\hline $\begin{array}{l}\text { Total Revenue } \\
\text { (Revenue and Grants) }\end{array}$ & 24.6 & 32.9 & 33 & 26.3 & 30.2 & 29.0 & 26.8 & 24.8 & 24.5 \\
Grants & 4.3 & 14.2 & 14.7 & 10.5 & 10.1 & 9.2 & 6.1 & 5 & 6.4 \\
Grants/Total & 17.5 & 43 & 44.5 & 40 & 33 & 31.7 & 22.3 & 20 & 26 \\
\hline
\end{tabular}

Source: Central Statistical Office, Quarterly Statistics 
The most important part of the budget balancing process has been expenditure reduction, though. Adam, Bevan and McBrady (1993a) argue that the fiscal squeeze in Zambia has been virtually unmatched in Africa and that it has been undesirably tight. Capital expenditures have been reduced, subsidies have been eliminated, military spending was reduced, and the civil service experienced severe real wage reductions. However, the financial liberalisation implied that interest charges on domestic debt were raised (Table 3).

Table 3: Selected expenditures by functional classification in percent of total expenditure, 1990-98

\begin{tabular}{llllllllll}
\hline & 1990 & 1991 & 1992 & 1993 & 1994 & 1995 & 1996 & 1997 & 1998 \\
\hline $\begin{array}{l}\text { General Public } \\
\text { services }\end{array}$ & 24.9 & 26.1 & 35.6 & 28.1 & 28.9 & 25.9 & 13.4 & 15.4 & 16.1 \\
Defence & 15.6 & 10.1 & 12.8 & 7.8 & 8.4 & 7.9 & 6.4 & 6.3 & 9.6 \\
Health & 10.3 & 5.9 & 6.2 & 8.4 & 8.8 & 9.2 & 9.4 & 11.1 & 10.8 \\
Education & 9.3 & 10.9 & 9.1 & 9.7 & 9.9 & 11.3 & 13.5 & 15.8 & 14.4 \\
Debt service & 5.9 & 6.6 & 11.8 & 24.1 & 20.4 & 12.8 & 17.2 & 13.1 & 11.4 \\
\hline
\end{tabular}

Source: Central Statistical Office, Quarterly Statistics

Together with the Economic Recovery Programme for the period 1991 to 1995, there was also a Rights Accumulation Programme (RAP) supported by the IMF. At the end of 1995 the government had made enough progress under RAP to resume borrowing from the IMF. This was the first time that Zambia had actually completed an agreement with the Fund.

During the first half of the 1990s, the government liberalised both maize and fertiliser marketing, eliminating the associated subsidies. This was a sweeping change that the government of the 1980s had had problems undertaking. Agricultural liberalisation was a highly controversial issue. The Kaunda government had introduced pan-territorial pricing to keep the prices of maize high also in peripheral regions. It then introduced maize subsidies to keep both producers and consumers happy. However, the poor agricultural response to reforms under the MMD could be blamed on poor policy sequencing. The sector was liberalised before macroeconomic stabilisation was achieved. The private sector was, for example, not ready to step in and buy the bumper maize harvest in 1993, while interest rates on government securities rose to $300 \%$. The government was forced to return to the agriculture market as a buyer, putting severe strain on the budget of 1994. In spite of this, and other implementation problems, the broader reforms remained on track.

Most of the labour market controls were also removed, but the most far-reaching liberalisation efforts were in the financial sector. The government freed interest rates in September 1992 and liberalised the Treasury bill market in January 1993. The immediate effect was a rise in interest rates and positive real rates were achieved in mid-1993 (Table 4). In February 1994, the government removed controls on the capital account for foreign payments.

Table 4: Monetary aggregates per cent, 1990-98

\begin{tabular}{llllllllll}
\hline & 1990 & 1991 & 1992 & 1993 & 1994 & 1995 & 1996 & 1997 & 1998 \\
\hline Velocity of money & 3.9 & 3.6 & 5.4 & 7.5 & 7.1 & 6.4 & 6.0 & 6.3 & 6.5 \\
Bank rate & 34 & 42 & 54 & 122.5 & 24.8 & 51.5 & 69.8 & 23.3 & 43.6 \\
Inflation & 107 & 97.7 & 165.7 & 183.8 & 54.6 & 34.9 & 43.1 & 24.4 & 24.5 \\
\hline
\end{tabular}

Source: Bank of Zambia 
The monetary stance has been to restrict the growth of money supply. The attempts were not very successful, however, until about 1993 when institutional reforms were introduced at the Bank of Zambia (Adam, Bevan and McBrady, 1993b). Money supply growth has since then been contained.

A Technical Committee on Privatisation was set up already in 1990, but no privatisation was undertaken before Kaunda's departure. Even after the MMD came in, progress was slow until about 1994, largely due to the very weak support for privatisation in the cabinet. The Zambian Privatisation Agency (ZPA) was launched in 1992, but by the end of 1993 only two firms had been privatised. During 1994 the donors pressed for more rapid reform. One serious conflict concerned Zambia Airways, which at the time received a subsidy from the government equal to about one per cent of GDP. Flights to Europe were often crowded with non-paying passengers such as ministers and their relatives. During the run up to the Consultative Group meetings in 1994, donors forced the government to close the airline. In the course of that year, two significant sales were made, that of Chilanga Cement and Zambia Breweries at US\$ 5.4 and US\$ 15.8, respectively. In the second half of 1995 the privatisation process gathered momentum, with the giant Zambia Sugar sold at US\$ 36.8. By the end of 1997 as many as 224 companies out of a total portfolio of 275 had been privatised. It was not until 1996, however, that the government acceded to the privatisation of ZCCM, the major asset. A very difficult process of tendering ensued, with the parties failing to reach foreclosure. The government lifted the ZCCM privatisation out of the Zambia Privatisation Agency and assigned it to a former head of the company. During 1998, ZCCM was losing one million dollars per day. There was finally an agreement at the end of 1999, which ironically meant that the bulk of the mining assets would revert to the original owner, the Anglo-American Corporation. The drawn out process for the privatisation of the mines had serious consequences for the economy, including the aid embargo imposed by donors in a bid to elicit progress on privatisation (World Bank, 1996).

The Public Sector Reform Programme was launched in 1993 with the aim of cutting the civil service by $25 \%$ over a three-year period, making it possible, thereby, to increase remuneration. However, while 15,000 contract employees were retrenched already in 1992, there has been no further retrenchment. Between 1991 and 1996, the civil service actually increased. The government argues that the social cost of retrenching civil servants is too high to make it a viable reform option. Still, the bloated and inefficient public service remains a serious growth constraint. The administrative capacity has also deteriorated further due to the heavy toll of HIV/AIDS.

GDP growth has been uneven during the reform period (Table 5). There has been drought, which has affected agriculture, while manufacturing output has been affected by the monetary squeeze, low internal demand and the parastatal reform. Manufacturing production had, by 1997, not yet returned to its 1991 level. The population growth rate fell from $3.1 \%$ to $2.4 \%$ per year over the period. Per capita incomes fell by more than a quarter between 1990 and 1998. The mining industry has faced problems throughout (Table 6), and the production problems of ZCCM have continued to affect GDP negatively. From 1993, mining production has shown a negative trend, even as the government was trying to privatise the mines (Table 7). We also note that terms of trade developments have shown a declining trend, largely 
driven by negative changes in copper prices (Tables 7 and 8). Finally we may also note that there has not been any significant recovery of investment in Zambia (Table 9).

Table 5: GDP and sector growth rates , 1990-98 (change in per cent)

\begin{tabular}{llllllllll}
\hline & 1990 & 1991 & 1992 & 1993 & 1994 & 1995 & 1996 & 1997 & 1998 \\
\hline Total GDP & -3.4 & -0.6 & 2.1 & -0.2 & -8.6 & -2.3 & 6.6 & 3.3 & -2.0 \\
Nonagriculture & -2.5 & -1.4 & 7.4 & -6.6 & -12.3 & -7.8 & 8.2 & 5.1 & -1.2 \\
Nonmining GDP & -2.4 & 1.4 & -0.1 & 1.8 & -12.5 & 2.8 & 7.2 & 3.5 & -0.8 \\
$\begin{array}{l}\text { Real GDP per } \\
\text { capita index }\end{array}$ & 100 & 96.4 & 95.6 & 92.6 & 81.6 & 73.6 & 76.5 & 77.5 & 73.2 \\
\hline
\end{tabular}

Source: Central Statistical Office, Quarterly Statistics

Table 6: Gross Domestic Product by sector of origin at current prices, 1990-98 (in per cent of GDP)

\begin{tabular}{llllllllll}
\hline & 1990 & 1991 & 1992 & 1993 & 1994 & 1995 & 1996 & 1997 & 1998 \\
\hline $\begin{array}{l}\text { Agriculture, forestry } \\
\text { and fishing }\end{array}$ & 18.2 & 15.8 & 21.3 & 30.5 & 13.5 & 16.2 & 15.5 & 16.3 & 17.3 \\
$\begin{array}{l}\text { Mining and } \\
\text { quarrying }\end{array}$ & 9 & 8.4 & 5.6 & 8.8 & 16.7 & 14.4 & 12.1 & 9.9 & 6.1 \\
$\begin{array}{l}\text { Manufacturing } \\
\text { Utilities }\end{array}$ & 31.9 & 33.3 & 33.2 & 25 & 9.8 & 9.9 & 11.8 & 11.8 & 11.4 \\
$\begin{array}{l}\text { Construction } \\
\text { Wholesale and retail }\end{array}$ & 5.4 & 5.9 & 5.7 & 5.5 & 9.2 & 9.1 & 9.1 & 9.3 & 9.7 \\
trade & 9.6 & 11.6 & 7.1 & 9.3 & 14.8 & 14.6 & 17.5 & 16.7 & 16.9 \\
$\begin{array}{l}\text { Financial and real } \\
\text { estate }\end{array}$ & 9.7 & 9.1 & 11 & 10.2 & 14.8 & 17.2 & 16.6 & 16.5 & 18.6 \\
Public sector & 6.2 & 6.4 & 7.5 & 6.9 & 8 & 8.4 & 7.1 & 8 & 9 \\
\hline
\end{tabular}

Source: Central Statistical Office, Quarterly Statistics

Note: Utilities include electricity, gas and water as well as transport and communications.

Table 7: Sales of Mineral Sales: From ZCCM's Book Balances

\begin{tabular}{llllllllll}
\hline & 1990 & 1991 & 1992 & 1993 & 1994 & 1995 & 1996 & 1997 & 1998 \\
\hline Sales & 1.47 & 1.42 & 1.34 & 1.43 & 1.01 & 1.11 & 1.08 & 0.97 & 0.85 \\
LME price & 90 & 80 & 78 & 65 & 79 & 100 & 78 & 78 & 56 \\
\hline
\end{tabular}

Source: ZCCM. The price series if from IMF (1999), IFS, and is in US cents/pound.

Table 8: Terms of trade, 1990-98

\begin{tabular}{llllllllll}
\hline & 1990 & 1991 & 1992 & 1993 & 1994 & 1995 & 1996 & 1997 & 1998 \\
\hline $\begin{array}{l}\text { Terms of Trade } \\
\text { index }(1990=100)\end{array}$ & 100 & 105.9 & 94.5 & 82.4 & 89.1 & 99.5 & 76.8 & 93.4 & 83.8 \\
Annual change $(\%)$ & 10.7 & 5.9 & -10.7 & -12.8 & 8.1 & 11.7 & -22.8 & 21.6 & -10.3 \\
\hline
\end{tabular}

Source: IMF

Table 9: Gross Domestic Product by type of expenditure, 1990-98 (in per cent of GDP)

\begin{tabular}{llllllllll}
\hline & 1990 & 1991 & 1992 & 1993 & 1994 & 1995 & 1996 & 1997 & 1998 \\
\hline Public Consumption & 14.8 & 16.2 & 17.9 & 13 & 14 & 16.3 & 18.1 & 16.6 & 15.7 \\
Private Consumption & 68.7 & 75.4 & 82.8 & 75.8 & 74.4 & 76.4 & 73.4 & 75.4 & 78.9 \\
Investment & 17.3 & 11 & 11.9 & 15 & 12.7 & 13.1 & 14.8 & 13.6 & 14 \\
Trade balance & -0.7 & -2.6 & -12.6 & -3.8 & -1.0 & -5.8 & -6.2 & -5.5 & -9.0 \\
\hline
\end{tabular}

Source: Central Statistical Office, Quarterly Statistics

The poor development of the economy has also been reflected in employment figures (Table 10). Paid formal sector employment is actually lower in 1998 than it was in 1990, and in particular we note the dramatic decline in industrial employment, including mining. The industry sector is now quite marginalised in the Zambian economy. 
Table 10: Paid Employment by sector ('000)

\begin{tabular}{llllllllll}
\hline & 1990 & 1991 & 1992 & 1993 & 1994 & 1995 & 1996 & 1997 & 1998 \\
\hline Public & 159 & 162 & 171 & 168 & 174 & 173 & 176 & 170 & 168 \\
Industry & 142 & 140 & 136 & 126 & 108 & 108 & 95 & 92 & 83 \\
Agriculture & 80 & 78 & 82 & 83 & 79 & 69 & 68 & 59 & 57 \\
Other & 162 & 164 & 158 & 143 & 136 & 135 & 140 & 155 & 157 \\
Total & 543 & 544 & 546 & 520 & 497 & 484 & 479 & 475 & 465 \\
\hline
\end{tabular}

Source: Central Statistical Office, Quarterly Statistics

The economic decline is also reflected in the deterioration of a range of social indicators. For example, under five mortality fell during the 1970s from 1800 per thousand to 149, but then increased to 197 in 1994. By 1997 there had been a slight reduction to 189 .

It has been argued by Rakner, van de Walle and Mulaisho (1999) that aside from the external shocks, the poor performance of the economy is due to lack of a coherent strategy for economic growth. It also seems quite likely that the slow reform of the mining sector, that always was politically difficult, did cost a lot in terms of lost momentum and financially in terms of subsidies throughout the 1990s. This footdragging also sent the wrong signal to potential investors about the government's reform commitment.

It is also clear that the debt burden is still a serious threat to the economy. There has of late been some progress on this front, however. In 1999, bilateral donors at the Paris Club expressed a willingness to write off up to two-thirds of their claims on the country, while there seems to be some support for speeding up Zambia's route to HIPC status.

\section{The politics of reform}

In 1991 Kaunda was replaced as president in a free and (reasonably) fair election. Zambian citizens played a major role in the change of regime as protesters against the old one and as supporters of the new Movement for Multiparty Democracy (MMD). Less than half the electorate participated in the election, however. With a near clean sweep of the votes, and with the autocratic legislation of Kaunda still intact, the new government soon came to abuse its power. Fear of an opposition plot to grab power in 1993, in favour of Kaunda, led to the declaration of a state of emergency. The MMD then changed the constitution to bar Kaunda from running in future elections. This met extensive opposition from the domestic press, civil society, opposition parties and donors. However, the government went ahead all the same. This then introduced a crisis of confidence in the country, with the government's economic policy credentials differing markedly from the democratic ones it was keen to establish.

Far from establishing a normal and democratic process of change of government, the second election of 1996 was instead boycotted by many opposition parties. Between the two elections, however, a gap seemed to have emerged between the incumbent parliamentarians and the constituents, and independent candidates managed to make inroads. Kees van Donge (1998) argues, however, that the opposition's attempts to use NGOs and donors to further its interests were not very successful. The charged political atmosphere finally led to a coup attempt in 1997, to which Chiluba 
responded both with the re-imposition of a state of emergency and the placing of Kaunda under house arrest.

The MMD government had initially come in with a team that was committed to political reform, but it was over the years replaced by younger and less experienced ministers, but with a stronger commitment to the President. Rakner, van de Walle and Mulaisho (1999, p. 35) argue that "the conduct of the elections proved that the Chiluba government was willing to compromise the rule of law, was intolerant of criticism and willing to exploit its majority position and control of government resources to undermine its opponents."

Other signs of a more autocratic approach are the possession by the President of a special account for "charitable donations". This is funded directly via the budget and is used to make very visible presidential donations to schools, churches etc. It is thus largely a conduit for the purchase of political support.

In spite of the setbacks there is still an independent press in Zambia, and the turn out in the 1996 elections was not worse than in 1991, indicating absence of voter apathy, while the local elections of 1998 were peaceful. There is also a fairly independent judiciary that has helped to keep politicians in check, while the Law Association and other civil society have criticised the government for imposing constitutional reforms from above.

\section{Donors and reform}

There are three aspects of the aid-reform relationship that may be considered in our discussion of Zambia, namely the impact of aid on the initiation of reform, on the policy content, and on the effectiveness of implementation. The content of reform packages has largely originated from IFIs or has been based on standard Structural Adjustment package, with limited original Zambian input. This has led to an ownership problem. With policymaking regarded as the exclusive preserve of the government, local groups have historically been excluded from policy debate. Still, while aid cannot buy policy change, there is evidence that conditionality sometimes has helped push reform forward, for example, with regard to privatisation (see e.g. discussion on Tanzania in Bigsten et al, 1999). In a recent evaluation of global Swedish aid, White (1999) has argued that it is mainly domestic political considerations that determine economic and political reform, not donors. A number of studies have shown that ownership is very important for policy efficacy, and that conditionality conflicts with ownership.

The negotiations with the IFIs under Kaunda were difficult, since their demands implied a critique of the "socialist" economic management pursued by Zambia. The reforms were thus at odds with the ideology of the ruling party, which therefore resisted it for as long as possible. The behaviour of donors varied over the different phases of the reform process. ${ }^{4}$ It is very hard to say for certain whether aid made reforms possible, but it may have induced them, at least in the sense that the government saw their adoption as a way of accessing aid. In this case, the government undertook them unwillingly, with resulting foot-dragging and policy reversals.

\footnotetext{
${ }^{4}$ For a discussion of the Swedish aid relationships with Zambia, see Adam et al (1994).
} 
During the 1990s, the policy environment improved considerably, both with regard to content and implementation. Still investments and growth have not been sufficient to raise per capita incomes, indicating that the reforms had no positive impact on average living standards, so far. It is not easy to determine to what extent this is to blame on structural shortcomings, such as a generally low level of competence or merely lack of commitment on the part of the government.

Will reforms be sustainable without aid? The answer hinges on whether aid actually buys reforms or whether reforms can be undertaken willingly, seen as the best option available. It is likely that the ineffectiveness of the policy implementation is partly to blame on the current aid relationship. Bilateral donors and the IFIs have been at odds several times and this lack of co-ordination has reduced their clout. Bilateral donors withheld balance of payments support after the exclusion of Kaunda from the 1996 elections, and once again when progress on the privatisation of the mines failed to materialise. There have also been complaints on governance issues. With regard to the regular aid programmes, however, the bilaterals have continued to pay up, while a major concern of the IFIs was to see to it that Zambia continued to service its debts. Thus while there is need for improvement in the country's governance structure, changes in the nature of the donor-Zambia relationship are necessary, with a view to enhancing ownership and mutual responsibility (for further discussion, see Collier, 1997,1999).

Thus, while it is clear that aid to Zambia has not had a strong payoff in terms of growth, constructing a realistic counterfactual of what would have happened if there had been less aid is extremely difficult. Donor support has exerted two kinds of influences on the country, that on the supply of external resources and on policy formation. Disentangling the two effects is crucial for assessing the impact of aid on growth. While the policy environment in Zambia, as normally defined, has certainly improved in the past decade, there is as yet no strong evidence that aid inflows have had a better growth impact in the past decade than in the 1980s.

\section{Discussion}

Most developing countries embark on reform under conditions of extreme economic fragility, lacking the resources necessary to buy the support of important socioeconomic groups. One major distortion in Zambia, at the start of its reforms, was that of an overvalued exchange rate, which derived from the country's pursuit of protectionist trade policies. Thus while there are a whole range of studies that show that openness is important for growth (see for example the review of the African evidence by Collier and Gunning, 1999a), there are high short-run political costs attached to the policy change. There were also costs related to the imposition of financial discipline, as illustrated by the introduction of the cash budget. While it helped raise fiscal integrity, it led to trade-offs between, for example, expenditures on health and education and support to the mines, with the former taking precedence in recent years. The cash budget was also circumvented by the government in at least two ways (Stasavage, Moyo, 1999): first, the government resorted to suppliers' credit, with domestic producers accumulating government debt. Another was to let the Bank of Zambia pay off some of the government's foreign debt, thereby building up the central bank's claims on the government. 
The above issues indicate that political pressures tend to lower policy commitment. Does this then reflect in lower investment? Although some African countries have managed to attract foreign investment in the past decade, international equity flows have almost completely bypassed Zambia. Since the investors' risk assessment depends on the credibility of policy reforms (Chibber et. al., 1992, World Bank, 1996) the persistent policy uncertainty in Zambia has caused investors to take a cautious attitude. The high level of indebtedness also raises the risk of policy reversal. Investment expansion thus requires long-term macroeconomic stability, and for this to be credible, debt burdens have to be manageable.

Zambia's experience also highlights the importance of policy sequencing. As pointed out above, agricultural reforms were undertaken before macroeconomic stability was achieved, reducing the extent of the agricultural response. Related to this was the slow rehabilitation of the road network making market access very difficult. Collier and Gunning (1999b) have argued that Zambia undertook financial adjustment measures, when in fact a fiscal stabilisation effort was what was required. Zambia's financial liberalisation was thus premature and thus had a negative effect on the economy. The move to capital account convertibility and interest rate liberalisation was also undertaken before stabilisation had been achieved. Inflation thus shot up, while real tax receipts declined. The government then reduced government expenditures by even more than planned.

However, ultimately policy implementation depends crucially on the nature of domestic institutions and politics (Dollar and Easterly, 1999). Dollar and Svensson (1998) find that the success of SAPs has depended on domestic institutional and political variables, such as rate of disbursements, and not on variables controlled by the World Bank, with democratically and newly elected governments tending to be more willing to implement reforms. In the early 1990s, Zambia moved towards democracy. While studies of the relationship between democracy and growth have been largely inconclusive, growth seems somewhat more likely to occur in countries where the population enjoys a degree of civil and economic liberties (see the review in Alesina and Perotti, 1994). In any case, political instability has a clearly negative effect on growth.

Still, the growth process will not become self-sustaining unless the recipient country has a reasonable measure of control over the policies being implemented. It is thus important that the reform process is not too heavily dependent on donors. The reform programme launched by the MMD started off with sweeping reforms of trade and exchange rate policies, and within a year it had launched a serious stabilisation effort. However, from about 1993, the reform process stagnated, the main problem areas being privatisation, public sector reform and governance. The limited progress here is explained by the effects, some contradictory, of domestic political competition as powerful groups vied for the control of the political and economic agenda, making it difficult for the government to send out coherent signals or to show commitment. Evidence shows that the latter is imperative if reforms are to be effectively implemented or have a significant impact (IMF, 1998).

The other aspect highlighted by Zambia is the difficulty of developing on a sustainable basis an active civil society. While many NGOs were engaged in the 
fight for democracy, feeling it to be their task to help in the dismantling of the one party state, once they had achieved their goal they ceased to operate or became simply less effective. Few have found it worth their while to continue to work towards the development of a democratic citizenship through political advocacy, monitoring of the government and education of citizens (Bratton et al, 1999). This absence of a 'watch dog', in a political environment dominated by the ruling MMD, probably partly explains the persistent charges of laxity and corruption in government.

It is also illustrative to look at the sources of opposition to the reforms under the MMD. The labour movement was the most vocal opponent of the government in the last years of the Kaunda regime and thus became a natural ally of the new government. In retrospect, however, removing Kaunda from office after close to 30 years in power, seemed more important than scrutinising the future policies of the MMD. As would be expected of a mass political movement, many of the original support groups had distanced themselves from the government already in the first year of the MMD's assumption of power. The labour movement has in the past decade been reduced in size, weakened by a poor labour market and new legislation against strikes (White 1999).

There was also potential opposition from the business community, which lost protection during the 1990s. However, it was mainly the smaller firms that were opposed to reforms, while the larger ones were mostly in favour. Moreover, the main beneficiaries of the former controls were state firms, which had by the early 1990s become seriously weakened. It was clear that these would suffer much more if the economy failed to recover from that state it was in during the early 1990s.

Public sector workers have not been a strong force against reform either. Those that have been retrenched have largely been lower grade workers that lacked voice, while those higher up in the hierarchy survived. The upper echelons of the civil service have also managed to preserve a reasonable standard of living in spite of low salaries through other means, for example, access to foreign travel or to donor initiated activities.

So who have been the winners? The political conflicts have not been primarily about the content of policy but about the division of the spoils enabled by access to business opportunities in the form of tenders or privatised businesses. Since the new political parties essentially consist of the same group of people as in the old system, the government cannot pursue the reform agenda without regard to the need for political support.

\section{Conclusions}

Although many elements of the reform package had been tried earlier, it was only the MMD government (since 1991) that pursued them on a sustained basis. In terms of macroeconomic stabilisation and market reform, the new government initially achieved a lot, and in spite of the implementation difficulties the reforms have remained on track. However, the government has been much less successful in terms of institutional reforms, especially in the areas of public-sector reform and governance. Even its privatisation efforts ultimately proved hard to complete. We 
argue that the latter type of reforms have more clear-cut costs for stakeholders and were, therefore, more likely to be resisted.

With regard to the poor growth results, it is plausible that the country is yet to establish the level of confidence that is required to attract sufficient amounts of domestic and foreign investment. In spite of the move towards multiparty democracy, the political process has been much harder to change in Zambia than was envisaged in the early 1990s. The political sphere thus continues to be the main stumbling block to durable reform.

With regard to the role of donors, aid to Zambia, or even its temporary withdrawal, has been a poor basis for inducing reform. The challenge for donors is therefore how to move away from policy conditionalities and instead to ensure that the country evolves an environment where aid can be more effective. Recipient countries need to feel that they are in control not only of the policy content of their reform programmes, but also of the pace of implementation. Ensuring a high degree of ownership on the part of host governments is the best way to enhance programme sustainability. 


\section{References}

Adam, C., Andersson, P., Bigsten, A., Collier, P., O'Connell, S. (1994), Evaluation of Swedish Development Co-Operation with Zambia. A Report for the Secretariat for Analysis of Swedish Development assistance, SASDA, Ds 1994:114, Ministry of Foreign Affairs, Stockholm.

Adam, C., Bevan, D. (1996), "Cash Budgets: Experience in Zambia", mimeo, CSAE, Oxford University, Oxford.

Adam, C., Bevan, D., McBrady, M. (1993a), "Macroeconomic performance in Zambia 1991-1993 part I: A review of the rights accumulation programme 1991-93", mimeo, CSAE, University of Oxford.

Adam, C., Bevan, D., McBrady, M. (1993b), "Macroeconomic performance in Zambia 1991-1993 part II: The fiscal implications of stabilisation and liberalisation measures", mimeo, CSAE, University of Oxford.

Alesina, A., Perotti, R. (1994), "The Political Economy of Growth: A Critical Survey of the Recent Literature", World Bank Economic Review, 8,3:351-372.

Andersson, P-Å., Bigsten, A., Persson, H. (1999), "Foreign Aid, Debt and Growth in Zambia," Department of Economics, University of Göteborg, mimeo.

Bates, R.H. Collier, P. (1993), "The Politics and Economics of Economic Reforms in Zambia", in R.H. Bates and A.O. Krueger (eds). Political and Economic Interactions in Economic Policy Reform, Blackwell, Oxford.

Bigsten, A., Mutalemwa, D., Tsikata, Y., Wangwe, S. (1999), "Aid and Reform in Tanzania”, http://www.worldbank.org/research/aid/africa/tanzania2.html.

Bratton, M., Alderfer, P., Browser, G. Temba, J. (1999), "The Effects of Civic Education on Political Culture: Evidence from Zambia”, World Development 27(5):807-824.

Bratton, M., van de Walle, N. (1997), Democratic Experiments in Africa: Regime Transitions in Comparative Perspectives, Cambridge University Press, London, New York.

Chibber, A. Dailami, M., Shafik, N. (eds) (1992), Reviving Private Investment in Developing Countries. Empirical Studies and Policy Lessons, North-Holland, Amsterdam.

Collier, P. (1997), "The Failure of conditionality", in C. Gwyn and J. Nelson (eds.), Perspectives on Aid and Development, Overseas Development Council, Washington, DC.

Collier, P. (1999), “Aid Dependency: A Critique", Journal of African Economies $8(4) ; 528-545$.

Collier, P., Gunning, J. (1999a), "Explaining African Economic Performance", Journal of Economic Literature 37(1).

Collier, P., Gunning, J. (1999b), “The IMF's role in structural adjustment”, WPS/9918, Centre for the Study of African Economies, Oxford University, Oxford.

Deaton, A. (1999), "Commodity prices and Growth in Africa", Journal of Economic Perspectives 13(3):23-40.

Dollar, D., Easterly, W. (1999), "The Search for the Key: Aid, Investment, and Policies in Africa", Journal of African Economies 8(4): 546-577.

Dollar, D., Svensson, J. (1998), "What Explains the Success or Failure of Structural Adjustment Programs?" mimeo, World Bank, Washington DC.

Hirschman, A.O. (1958), Strategy of Economic Development, Yale University Press, New Haven. 
IMF (1998), External Evaluation of the ESAF, report by a group of independent experts, Washington DC.

IMF (1999), International Financial Statistics, CD-rom.

Kayizzi-Mugerwa, S. (1997), "The Political Economy of Mineral Dependence: Dutch Disease Impacts on Zambia", in Mwega, F.M., Seshamani, V. (eds.), Economic management in Sub-Saharan Africa, East African Education publishers, Nairobi.

Kees van Donge, J. (1998), "Reflections on donors, opposition and popular will in the 1996 Zambian general elections", Journal of Modern African Studies 36(1):71-99.

MMD (1991), Election Manifesto, Lusaka.

Mwenda, A. (1999), "Monetary Policy Effectiveness in Zambia", in KayizziMugerwa, S. (ed.), The African Economy. Policy, institutions and the future, Routledge, London.

Rakner, L., van de Walle, N., Mulaisho, D. (1999), “Aid and Reform in Zambia: Country Case Study", World Bank programme on Aid and Reform in Africa, WB homepage.

Sachs, J. D., Warner, A.M. (1997), "Sources of Slow Growth in African Economies", Journal of African Economies 6(3): 335-376.

Sachs, J. D., Warner, A.M. (1995), "Natural Resource Abundance and Economic Growth", NBER Working Paper no 5398, NBER, Cambridge MA.

Stasavage, D., Moyo, D. (1999), "Are cash budgets a cure for excess fiscal deficits (and at what cost)?, Working Paper no 99-11, Centre for the Study of African Economy, Oxford University.

White, H. (1999), A Black Sheep Among the Reformers: Programme Aid to Zambia, Sida Evaluation Report 99:17/8, Sida, Stockholm.

World Bank (1996), “Zambia - prospects for sustainable growth 1995-2005”, Report no. $15477-\mathrm{ZA}$. 